\title{
Hurdles in fungal taxonomy: Effectiveness of recent methods in discriminating taxa
}

\author{
K.W.T. CHETHANA ${ }^{1,2}$, RUVISHIKA S. JAYAWARDENA ${ }^{1,3} \&$ KEVIN D. HYDE ${ }^{1,4,5, *}$ \\ *Corresponding author: झ" kdhyde3@gmail.com \\ ${ }^{1}$ Center of Excellence in Fungal Research and School of Science, Mae fah Luang University, Chiang Rai, Thailand \\ 2 "”tchethi@yahoo.com; — https://orcid.org/0000-0002-5816-9269 \\ 3 इ" ruvi.jaya@yahoo.com; † https://orcid.org/0000-0001-7702-4885 \\ [" kdhyde3@gmail.com; ○ https://orcid.org/0000-0002-2191-0762 \\ ${ }^{5}$ Key Laboratory for Plant Diversity and Biogeography of East Asia, Kunming Institute of Botany, Chinese Academy of Sciences, \\ Kunming 650201, People's Republic of China
}

\begin{abstract}
The fungal kingdom is estimated to comprise between 2.2 to 3.8 million species with only about $7 \%$ named and classified. Novel biochemical, physiological and molecular techniques have been utilized to improve the systematics of fungal taxa and estimates of their diversity. Multidisciplinary approaches should be used for resolving species and higher taxa of the fungi. However, even with all the benefits of the new techniques, they are also providing unclear results and taxonomic instability. Taxonomists should be aware of these issues and should follow pragmatic approaches. In order to overcome these taxonomic challenges, cooperation and communication among mycologists worldwide are crucial for the study of fungal diversity.
\end{abstract}

\section{Introduction}

The kingdom fungi has an enormous species diversity with varied morphologies, ecologies and nutritional modes, many of which have biotechnological, medicinal and industrial importance (Hyde et al. 2019). With this extraordinary species richness, fungal systematics and classification face huge challenges. Taxonomy is a part of the scientific practice that deals with naming, describing and classifying fungal species (Katoch \& Kapoor 2014). The current classification system, which is based on Linnaean ranks, has been criticized by many taxonomists and a new dialogue has been opened for the possibility of moving toward a rankless taxonomic framework or applying combined balanced quantitative methods to determine ranks, such as applying temporal banding and phenotypic disparity (Vasilyeva \& Stephenson 2010; Casiraghi et al. 2016; Kraichak et al. 2017; Kraichak et al. 2018; Lücking 2019). Here, we discuss three challenges to both traditional morphology and molecular phylogenetics.
First, we discuss differences between phylogenetics and phylogenomics and when to use which approach. Next, we focus on issues of how to define higher ranks in the classification system. Then we discuss future directions in mycology, specifically towards exploring undiscovered fungal taxa. Finally, we conclude with a positive note and look at ways we can integrate the study of fungal taxonomy with applied aspects.

\section{Single and multi-gene phylogenetics vs.} phylogenomics: What \& when to use?

Traditional approaches in taxonomy and systematics were mainly based on morphology. There are several aspects that affect the results of a morphology-based classification such as pleomorphism, homoplasy, phenotypic stasis and cryptic speciation within fungal taxa. With the discovery of these aspects, the taxonomy of the organisms has become less certain. As a result, in the early 1990s, DNA sequence data (especially $18 \mathrm{~S}$ ribosomal DNA), emerged as a new approach for delineating species. In addition to DNA sequence data, other molecular techniques such as amplified fragment length polymorphism, restriction fragment length polymorphism and randomly amplified polymorphic DNA, have been employed in the classification and taxonomy of various organisms in different kingdoms (Williams et al. 1990; RoeckelDrevet et al. 1997). DNA sequence data from fungi has accumulated exponentially and resulted in the establishment of many accepted relationships between fungi (Wingfield et al. 2012; Peršoh 2015; Balint et al. 2016; Samarakoon et al. 2016; Spatafora et al. 2016; Tedersoo et al. 2018). Another benefit of the molecular approach is that it has revealed fungal taxa that would not have been detected using traditional culturing techniques. 
Phylogenetics is a dynamic discipline that reconstructs and analyses the evolutionary relationships of species or taxa (Wiley \& Lieberman 2011; Young \& Gillung 2020). Initially, most phylogenetic papers were based on nuclear ribosomal RNA genes (rDNA) (Bruns et al. 1991; Hibbett 1992; Hwang \& Kim 1999; Schoch et al. 2009, 2012) as these multicopy genes are highly conserved within a species and can vary among species (Bruns et al. 1991; Hibbett 1992; Xu 2006). As different regions of these rDNA genes evolve at different rates, they are useful to resolve lineages at different taxonomic levels, for example, SSU and LSU rDNA are generally applied at higher taxonomic level delineation (Schoch et al. 2012; Zhang et al. 2017). However, protein-coding genes and non-functional DNA fragments are better suited when performing comparisons within a species as they are more informative than the highly conserved rDNA genes. This less informativeness in rDNA genes has resulted from the strong concerted evolution pressure, while the noncoding sequences and third base substitutions have been subjected to fewer constraints (Lutzoni et al. 2004; Xu et al.2006). However, these single copy protein-coding genes together with the rDNA genes provide relatively higher resolution compared to single gene phylogenies (Liu et al. 1999; Hong et al. 2005; Zhang et al. 2012). Multi-locus phylogenetic analysis was developed by combining all available phylogenetic data and has been considered as a better alternative to single gene phylogeny as it increases the informativeness, helps resolve nodes, nodal branching and improves phylogenetic accuracy (Zhang et al. 2006; Chen et al. 2015; Maharachchikumbura et al. 2016; Hyde et al. 2017a, 2018). With the advent of new sequencing strategies and bioinformatic approaches for analyzing large amounts of data (Karp et al. 2002; McDermott et al. 2005), together with the continuing decrease in sequencing costs (Margulies et al.2005), there has been an exponential growth in the availability of fungal genomic data. These fungal whole genome or transcriptome data intertwined together with the developments of phylogenetics have resulted in the emergence of the new field of phylogenomics, which is the study of evolutionary relationships based on comparative analyses of genome scale data (Tatusov et al. 2003; Chan \& Ragan 2013).

The use of either phylogenetic or phylogenomic approaches depends on the user perspectives, the amount of the data available for the study and the objectives of the study. If the study objective is to perform species delimitation for several fungal taxa or even for many fungal taxa using multiple gene regions $(<10)$, then a multi-gene phylogenetic approach is more suitable. However, if the study requires to infer phylogenetic relationships between taxa to understand the mechanisms of molecular evolution or to use multispecies phylogenetic comparisons to infer putative functions for DNA or protein sequences, then phylogenomic approaches are justifiable. These phylogenomic approaches work on genomic data, which are 10-1000× larger than the typical multi-gene phylogenetic dataset. Therefore, phylogenomics has the potential to improve resolution by reducing the stochastic error resulting from the finite length of sequences used in the inference (Som 2015; Nafy \& Szollosi 2017). Due to the shallow relationships existing among higher ranks, phylogenomic approaches can be used for better resolution in the tree of life (Spatafora et al. 2017; EwersSaucedo et al. 2019). Therefore, if the resources and the time is available, phylogenomics can be used to infer the relationships or the classification of higher ranks. In recent studies, divergence times based on a molecular clock has been used as an effective and robust approach for taxonomic distinction (Zhao et al. 2016, 2017). Phylogenomic studies have been used to resolve fungi with controversial evolutionary relationships. For example, Fu et al. (2020) suggested the use of genome coverage and genome mapping ratios as reliable, universal taxonomic criteria at the genus level for fungi.

Despite holding considerable promise, phylogenomics also has some pitfalls due to the limitations of the existing phylogenetic reconstruction methods, prevalence of nonphylogenetic signals and inability to form fundamental assumptions in genome scale data sets (Jeffroy et al. 2006). Even with these pitfalls, there is evidence supporting the importance and the usefulness of phylogenomic analyses to resolve evolutionary patterns and relationships between the higher ranks in the fungal taxonomy. For example, evidence for the relationship between Leotiomycetes and Sordariomycetes (Fitzpatrick et al. 2016), positioning of Xylonomycetes among the fungi (Gazis et al. 2016), the paraphyletic nature of Zygomycota (Liu et al. 2009), and the construction of kingdom-wide fungal phylogeny including the early lineages, Ascomycota and Basidiomycota (Ebersberger et al. 2012), can be listed as examples resolved by phylogenomic analyses. Therefore, it is highly recommended to utilize more genomic scale data to improve phylogenetic resolution and form a foundation for fungal taxonomic and systematic research. The drive towards next-generation phylogenomics has been initiated and entered a period of improvement. More than 1000 genome projects using phylogenomic techniques have been initiated and are being used to provide answers to long-standing phylogenetic problems at all levels of the tree of life. Despite its pitfalls, phylogenomic data have helped resolve many long-standing questions. Genome-scale datasets yield a dramatic increase in our statistical confidence of inferred relationships, resulting in maximally supported species trees. Therefore, if the data and resources are available, phylogenomic approaches should be employed to resolve fungal relationships. 
02. Defining higher ranks in the classification system: can we justify monospecific families and can all taxonomists have a common ground?

Higher taxonomic ranks, such as classes, orders and families are not natural entities, but human constructs that are defined for the benefit of taxonomists (Laurin 2010; Liu et al. 2016; Hyde et al. 2017b). However, based on evolutionary aspects, there is an argument that these entities do naturally exist and the inability to recognize these evolutionary relationships has led to the conclusion of higher ranks being artificial human constructs (Ereshefsky 2007; Lücking 2019). When we discuss the delineation of higher taxa, their consistency is based on evolutionary theories. According to evolutionary theory, phenotypic stasis or stability is the result of natural selection and genetic drift or caused by mutation and recombination events among populations (Lücking 2019; Mallard et al. 2019). However, this evolutionary consistency can clearly be observed at the genus level and below. Therefore, when defining families, orders and classes, taxonomists should follow a combined approach that best reflect their individual evolutionary history.

In higher-level taxonomy, another major challenge faced by taxonomists is the justification of monospecific families. The accepted number of fungal families has risen from 536 to 886 during the past decade, mainly due to the rapid increase in the use of DNA sequence data in defining families (Wijayawardene et al. 2017, 2018a, b). There are families with over 1000 species and also some with only a single known species. There are 57 such monospecific fungal families (Kew Report 2018). A monospecific family is described based on a single genus with a single species. From a conservation point of view, these families are important as they may represent species-rich relic taxa from early lineages, that hold a unique gene pool. For example, Bartheletiaceae is a family with a single species, Bartheletia paradoxa. These families deserve considerable attention as if we ignore them, there is a possibility that they could be lost forever (Samarakoon et al. 2016). Limitations associate with locating and loaning the herbaria of these monospecific families include, lack of reference data due to loss or damage, or not being available in the public domain and ruined or damaged fungal material (Dayarathne et al. 1998). For example, the herbarium of the monospecific Hypocreodendron sanguineum Henn. (1897) deposited by Hennings was destroyed by fire. Another issue with studying monospecific families is that their re-collection is difficult due to the destruction of their original habitats by human interference (Hyde et al. 1998).

In recent years, the introduction of monospecific families has increased due to the sole dependency on DNA sequence data. Ascocylindricaceae (Ariyawansa et al. 2015b) is an example. In some instances, these monospecific families have resulted because of inadequate sampling. Therefore, mycologists and taxonomists should consider following a polyphyletic approach to define higher ranks, such as families, orders and classes. However, to date, there is no universal taxonomic criterion for defining higher ranks in fungal taxonomy (Samarakoon et al. 2016). Even though mycologists have attempted to establish more reliable methods, it has always been contentious, subjective and resulted in unnecessary conflicts (Liu et al. 2016; Divakar et al. 2017; Hyde et al. 2017b). For example, the three families namely Endomelanconiopsisaceae, Pseudofusicoccumaceae and Septorioideaceae were treated as genera pending further sampling and phylogenetic support by Liu et al. (2016) due to their few morphological or ecological characters. However, Crous et al. (2017) and Wijayawardene et al. (2018a) accepted nine families including the above in Botryosphaeriales. Phillips et al. (2019) then used a polyphasic approach (morphological studies, phylogenetic analyses and evolutionary study) and synonymized Endomelanconiopsisaceae, Pseudofusicoccumaceae and Septorioideaceae under Botryosphaeriaceae, Phyllostictaceae and Saccharataceae, respectively.

In order to avoid the confusions related to monospecific families some taxonomists have placed monospecific genera such as Pseudoxylomyces under Dothideomycetes genera incertae sedis rather than introducing new families (Ariyawansa et al. 2015a, b). In another approach to addressing this problem, Phillips et al. (2019) employed the morphology of sexual morph, phylogenetic relationships and evolutionary divergence times of lineages in relation to major events in the evolution of their hosts on a geological timescale for the re-assessment of families in Botryosphaeriales. Following the same integrative approach, Lücking (2019) proposed to use comparative phenotype divergence combined with branch length pattern analysis, in order to reflect the individual evolutionary history of higher-level taxa. This means that nomenclature of higher taxa has to find a balance between scientific evidence of evolutionary relationships and the arbitrary decision of what rank a higher taxon should receive (Hyde et al. 2017b).

\section{Exploring the undiscovered based environmental sequences: valid or invalid?}

Fungal taxonomy pursues discovering, describing and classifying all species of fungi and also provides tools for their identification. It is necessary to accelerate the pace of species description, to develop a complete catalogue of fungal diversity within a reasonable time frame, before the species become extinct. However, it is unlikely that 
this goal will be achieved in the near future due to the disadvantages of traditional morphology-based taxonomy and the massive number of active taxonomists required (Hibbett et al. 2011).

The most common limitation of traditional morphology-based taxonomy analysis is limited or overlapping morphological characters. The development of molecular phylogeny has revealed an unexpectedly high fungal diversity. For example, studies with molecular phylogenetics have demonstrated that many morphologically similar taxa might represent distinct lineages, and many well-known species are in fact species complexes, such as in the genera Colletotrichum and Diaporthe (Dai et al. 2015). However, traditional molecular tools are most applicable to cultivatable and fast-growing species isolated from the environment, whose DNA can be extracted from single spore isolates or from fresh specimens. This approach, however, cannot be applied to unculturable fungi (Hongsanan et al. 2018). This limitation has now been overcome via cultureindependent techniques, specifically metagenomics (Blackwell 2011).

Next-generation sequencing approaches have resulted in a huge number of unidentified fungal taxa or operational taxonomic units (OTUs) from various habitats (Davison et al. 2018). These OTUs generally consist of ITS and more recently SSU and LSU sequences obtained from environmental genomic DNA (Womack et al. 2015; Hongsanan et al. 2018). Even though the assignment of sequences to OTUs are obtained by different algorithms and threshold levels, the resulting OTUs can be the same across different habitats (Schmidt et al. 2014). Due to lack of taxonomic information in fungal databases, most OTUs are not often classified at different taxonomic ranks and are considered as "unclassified" in the analyses. Wu et al. (2019) estimated that the total fungal diversity is about 12 million species based on both culture dependent and independent methods.

With all its benefits, the use of environmental genomic DNA to define species also has its problems. A consequence of using environmental DNA to define species has resulted in introducing numerous dark taxa into light (Grossart et al. 2016). Dark taxa are fungal taxa introduced only from sequence data and cannot be linked to any physical specimen or resolved taxonomic name (Hongsanan et al. 2018; Ryberg \& Nilsson 2018). Introduction of dark taxa is against article 38 of nomenclature and typification (Art. 7-10) (McNeil et al. 2012). Another major issue with environmental DNA sequence data is the inability to reproduce and verify; the latter will result in numerous erroneous sequences. However, the connection between a fungal species introduced based on morphology and phylogeny and species introduced as OTUs based on the similarity threshold is challenging and needs to be answered by the mycological community (Dissanayake et al. 2018; Hongsanan et al. 2018; Jayawardena et al. 2018). Therefore, efforts must be taken to obtain physical cultures of specimens as proposed by Hongsanan et al. (2018) and Wu et al. (2019). Introducing species based on mgDNA data at this time cannot be accepted. There is also a risk of describing already known species or the dark taxa. Although Hawksworth et al. (2018) was in favour of accepting environmental DNA as types, this was downvoted by the International Mycological Congress (IMC) nomenclatural session in 2018 and a special purpose committee was proposed to investigate this issue further and to report back in IMC 2022 (May et al. 2018). However, dark taxa cannot be ignored in the future, with the development of new technology and increased use of environmental barcoding in species delimitation. Therefore, Lücking et al. (2018) proposed that repositories should allow sequence-based names to be registered and should allocate an identifier for future communication as in the UNITE database (Nilsson et al. 2018). Sequence-based fungal nomenclature can be introduced with careful and strict guidelines to ensure high-quality data and reproducibility.

\section{Conclusion}

With all of the advanced technologies and newly developed techniques, there are still disagreements in species delimitation and species conceptualization. These disagreements have led to debates as to species definitions and methods used to infer both species boundaries and their numbers. There are many species concepts in work today including both conventional concepts (biological, morphological, ecological and phylogenetics) and modern concepts (consolidated species concept) and techniques (Genealogical concordance phylogenetic species recognition, coalescent based techniques and phylogenomic approaches). Projects have been initiated by ICFT and others towards establishing guidelines for a polyphasic approach to species boundaries which can be generalized towards all fungi and can also be applied to resolve specific species complexes.

Hyde et al. (2011) discussed the diminishing number of mycologists, especially in Europe and the USA, against a backdrop of the huge numbers of fungi awaiting discovery. With fewer fungal taxonomists, how could such large numbers of fungi be described before they become extinct? The answer seemed very gloomy. However, every cloud has a silver lining and there has been an explosive burst in the study of fungi in Asia and to a lesser extent in South America. There are many reasons for this, one being that fungi are greatly appreciated in Asia and especially in China. Mushrooms are consumed and 
used as traditional medicine in astonishing amounts, and mushroom farms and medicinal production facilities have grown up across the region. It has also meant that fungal taxonomy has once again become important in the quest to discover new edible or medicinal taxa. Mushrooms are also gathered throughout Asia and again particularly in China. Therefore, it is important that people know what they are collecting and eating, and that poisonous species are also documented.

Novel chemical discovery has been a huge area of research, particularly when applied to plants. However, fungi are also a treasure trove of novel medicinal compounds which have been understudied and therefore research into this aspect has grown and will grow further. De Silva et al. (2012a,b, 2013) reviewed the research on ways in which the fungi can be used in cancer, diabetes and other illness treatments. Hyde et al. (2019) covered 50 ways in which fungi can be used in industry and most with research in its infancy. This included biocontrol, biofertilizers, novel packaging, dyes and novel drugs. With such a huge undiscovered diversity and so many applications it is no wonder more research is being carried and the fungi await serious exploitation.

The future of fungal taxonomy is challenging. Traditional morphological studies are still very important, as species names are needed in plant pathology, quarantine and most applied industrial aspects. Yet morphology alone is inadequate and far too subjective for some fungal groups such as Diaporthe, Colletotrichum, Pestalotiopsis, Coniella and many others. Therefore taxonomists must incorporate modern techniques, such as phylogenetics, genomics, metabolomics and evolutionary approaches. However, this increases costs and creative methods are needed to apply for funding. However, if all cultivable fungi are isolated and placed in repositories (i.e. culture collections) for other research, then value is added to the basic taxonomy results. For instance, MFU has a growing collection of over 10,000 strains of fungi of which more than 2,000 are named species, from across the entire Kingdom and provides a significant contribution to Asian mycology. This resource is a gold mine for further applications and potential drug discoveries such as Ophiocordyceps sinensis capsules, SX-Fraction, ReishiMax capsules and Tremella used anti-diabetic drugs and many other medicinal mushrooms used in traditional Chinese medicines (Hyde et al. 2019). Therefore linking traditional taxonomy with modern techniques and a resource collection for applied research may well be a good way forward. Even though we discussed the above three taxonomic problems related to fungi, these questions can also be appied to other Kingdoms and general taxonomy.

\section{Funding}

We thank the Thailand Research Fund for the grant RDG6130001 entitled "Impact of climate change on fungal diversity and biogeography in the Greater Mekong Subregion".

\section{References}

Ariyawansa, H.A., Hyde, K.D., Jayasiri, S.C., Buyck, B., Chenthana, K.W.T., Dai, D.Q., Dai, Y.C, Daranagama, D.A., Jayawardena, R.S., Lücking, R., Ghobad-Nejhad, M., Niskanen, T., Thambugala, K.M., Voigt,K., Zhao, R.L., LiG, J., Doilom, M., Boonmee, S., Yang, Z.L., Cai, Q., Cui, Y.Y., Bahkali, A.H., Chen, J., Cui, B. K., Chen, J.J., Dayarathne, M.C., Dissanayake, A.J., Ekanayaka, A.H., Hashimoto, A., Hongsanan, S., Jones, E.B.G., Larsson, E., Li, W.J., Li, Q.R., Liu, J.K., Luo, Z.L., Maharachchikumbura, S.S.N., Mapook, A., McKenzie, E.H.C., Norphanphoun, C., Konta, S., Pang, K.L., Perera, R.H., Phookamsak, R., Phukhamsakda, C., Pinruan, U., Randrianjohany, E., Singtripop, C., Tanaka, K., Tian, C.M., Tibpromma, T., Abdel-Wahab, Mohamed A., Wanasinghe, D.N., Wijayawardene, N.N., Zhang, J.F., Zhang, H., Abdel-Aziz, F.A., Wedin, M., Westberg, M., Ammirati, J.F., Bulgakov, Timur S., Lima, D.X., Callaghan, T.M., Callac, P., Chang, C.H., Coca, L.F., Dal-Forno, M., Dollhofer, V., Fliegerova, K., Greiner, K., Griffith, G.W., Ho, H.M., Hofstetter, V., Jeewon, R., Kang, J.C., Wen, T.C., Kirk, P.M., Kytövuori, I., Lawrey, J.D., Xing, J., Li, H., Liu, Z.Y., Liu, X.Z., Liimatainen, K., Lumbsch, T.H., Matsumura, M., Moncada, B., Nuankaew, S., Parnmen, S., Santiago, A.L.C.M.D.A., Sommai, S., Song, Y., deSouza, C.A.F., deSouza-Motta, C.M., Su, H.Y., Suetrong, S., Wang, Y., Wei, S.F., Yuan, H.S., Zhou, L.W., Réblová, M., Fournier, J., Camporesi, E., Luangsa-ard, J.J., Tasanathai, K., Khonsanit, A., Thanakitpipattana, D., Somrithipol, S., Diederich, P., Millanes, A.M., Common, R.S., Stadler, M., Yan, J.Y., Li, X.H., Lee, H.W., Nguyen, T.T.T., Lee, H.B., Battistin, E., Marsico, O., Vizzini, A., Vila, J., Ercole, E., Eberhardt, U., Simonini, G., Wen, H.A., Chen, X.H., Miettinen, O., Spirin, V. \& Hernawati, H. (2015a) Fungal diversity notes 111252 - taxonomic and phylogenetic contributions to fungal taxa. Fungal Diversity, 75, 27-274.

https://doi.org/10.1007/s13225-015-0346-5

Ariyawansa, H.A., Phukhamsakda, C., Thambugala, K.M., Bulgakov, T.S., Wanasinghe, D.N., Perera, R.H., Mapook, A., Camporesi, E., Kang, J-C., Jones, EBJ., Bahkali, A.H., Jayasiri, S.C., Hyde, K.D., Liu, Z-Y. \& Bhat, J.D. (2015b) Revision and phylogeny of Leptosphaeriaceae. Fungal Diversity, 74, 19-51.

https://doi.org/10.1007/s13225-015-0349-2

Bálint, M., Bahram, M., Eren, A.M., Faust, K., Fuhrman, J.A., Lindahl, B., O’Hara, R.B., Öpik, M., Sogin, M.L., Unterseher, M. \& Tedersoo, L. (2016) Millions of reads, thousands of taxa: microbial community structure and associations analyzed via marker genes. FEMS microbiology reviews, 40, 686-700. https://doi.org/10.1093/femsre/fuw017

Barrett, M., Donoghue, M.J. \& Sober, E. (1991) Against consensus. Systematic Zoology, 40, 486-493. https://doi.org/10.2307/2992242 
Bininda-Emonds, O.R.P. (2004) The evolution of supertrees. Trends in Ecology and Evolution, 19, 315-322. https://doi.org/10.1016/j.tree.2004.03.015

Blackwell, M. (2011) The fungi: 1, 2, 3 ... 5.1 million species? American Journal of Botany, 98, 426-438.

Bruns, T.D., White, T.J. \& Taylor, J.W. (1991) Fungal molecular systematics. Annual Review of Ecology and Systematics, 22, $525-564$

https://doi.org/10.3732/ajb.1000298

Cannon, P.F. \& Kirk, P.M. (Eds.) (2007) Fungal families of the world. Cabi, Oxfordshire, $455 \mathrm{pp}$.

Casiraghi, M., Galimberti, A., Sandionigi, A., Bruno, A. \& Labra, M. (2016) Life with or without names. Evolutionary Biology, $43,582-595$. https://doi.org/10.1007/s11692-016-9384-5

Chan, C.X. \& Ragan, M.A. (2013). Next-generation phylogenomics. Biology direct, $8,3$. https://doi.org/10.1186/1745-6150-8-3

Chen, Q., Jiang, J.R., Zhang, G.Z., Cai, L. \& Crous, P.W. (2015) Resolving the Phoma enigma. Studies in Mycology, 82, 137217. https://doi.org/10.1016/j.simyco.2015.10.003

Comas, I., Moya, A. \& González-Candelas, F. (2007) From phylogenetics to phylogenomics: the evolutionary relationships of insect endosymbiotic $\gamma$-Proteobacteria as a test case. Systematic biology, 56, 1-16. https://doi.org/10.1080/10635150601109759

Crous, P.W., Slippers, B., Groenewald, J.Z. \& Wingfield, M.J. (2017) Botryosphaeriaceae: systematics, pathology, and genetics. Fungal Biology, 121, 305-306. https://doi.org/10.1016/j.funbio.2017.01.003

Dai, Y.-C., Cui, B.-K., Si, J., He, S.-H., Hyde, K.D., Yuan, H.-S., Liu, X.-Y. \& Zhou, L.-W. (2015) Dynamics of the worldwide number of fungi with emphasis on fungal diversity in China. Mycological Progress, 14, 1-9. https://doi.org/10.1007/s11557-015-1084-5

Davison, J., Moora, M., Öpik, M., Ainsaar, L., Ducousso, M., Hiiesalu, I., Jairus, T., Johnson, N., Jourand, P., Kalamees, R. \& Koorem, K. (2018) Microbial island biogeography: isolation shapes the life history characteristics but not diversity of root-symbiotic fungal communities. The ISME Journal, 12, 2211-2224 https://doi.org/10.1038/s41396-018-0196-8

Dayarathne, M.C., Boonmee, S., Braun, U., Crous, P.W., Daranagama, D.A., Dissanayake, A.J., Ekanayaka, H., Jayawardena, R., Jones, E.B.G., Maharachchikumbura, S.S.N., Perera, R.H., Phillips, A.J.L., Stadler, M., Thambugala, K.M., Wanasinghe, D.N., Zhao, Q., Hyde, K.D. \& Jeewon, R. (2016) Taxonomic utility of old names in current fungal classification and nomenclature: Conflicts, confusion \& clarifications. Mycosphere, 7, 1622-1648. https://doi.org/10.5943/mycosphere/7/11/2

Delsuc, F., Brinkmann, H. \& Philippe, H. (2005) Phylogenomics and the reconstruction of the tree of life. Nature Review Genetics, 6, 361-375. https://doi.org/10.1038/nrg1603

De Silva, D.D., Rapior, S., Fons, F., Bahkali, A.H. \& Hyde, K.D. (2012a) Medicinal mushrooms in supportive cancer therapies: an approach to anti-cancer effects and putative mechanisms of action. Fungal Diversity, 55, 1-35. https://doi.org/10.1007/s13225-012-0151-3

De Silva, D.D., Rapior, S., Hyde, K.D. \& Bahkali, A.H. (2012b) Medicinal mushrooms in prevention and control of diabetes mellitus. Fungal Diversity, 56, 1-29.

https://doi.org/10.1007/s13225-012-0187-4

De Silva, D.D., Rapior, S., Sudarman, E., Stadler, M., Xu, J., Alias, S.A. \& Hyde, K.D. (2013) Bioactive metabolites from macrofungi: ethnopharmacology, biological activities and chemistry. Fungal Diversity, 62, 1-40. https://doi.org/10.1007/s13225-013-0265-2

Dissanayake, A.J., Purahong, W., Wubet, T., Hyde, K.D., Wei, Z., Xu, H.Y., Zhang, G.J., Yuan, F.C., Liu, M., Xing, Q., Li, X.H. \& Yan, J.Y. (2018) Direct comparison of culture dependent and culture independent molecular approaches reveal the diversity of fungal endophytic communities in stems of grapevine (Vitis vinifera). Fungal Diversity, 90, 85-107. https://doi.org/10.1007/s13225-018-0399-3

Divakar, P.K., Crespo, A., Kraichak, E., Leavitt, S.D., Singh, G., Schmitt, I. \& Lumbsch, H.T. (2017) Using a temporal phylogenetic method to harmonize family and genus-level classification in the largest clade of lichen-forming fungi. Fungal Diversity, 84, 101-117. https://doi.org/10.1007/s13225-017-0379-z

Ebersberger, I., de Matos Simoes, R., Kupczok, A., Gube, M., Kothe, E., Voigt, K. \& von Haeseler, A. (2012) A consistent phylogenetic backbone for the fungi. Molecular Biology and Evolution, 29, 1319-1334.

https://doi.org/10.1093/molbev/msr285

Ereshefsky, M. (2007) Species, taxonomy, and systematics. In: Philosophy of Biology; Matthen, M \& Stephens, C. (Eds.), North-Holland (Elsevier), Amsterdam, 401-427 pp.

Ewers-Saucedo, C., Owen, C.L., Pérez-Losada, M., Høeg, J.T., Glenner, H., Chan, B.K. \& Crandall, K.A. (2019) Towards a barnacle tree of life: integrating diverse phylogenetic efforts into a comprehensive hypothesis of thecostracan evolution. Peer Journal, 7, e7387. https://doi.org/10.7717/peerj. 7387

Fitzpatrick, D.A., Logue, M.E., Stajich, J.E. \& Butler, G. (2006) A fungal phylogeny based on 42 complete genomes derived from supertree and combined gene analysis. BMC Evolutionary Biology, 6, 99. https://doi.org/10.1186/1471-2148-6-99

Fu, Y., Sun, L., Fu, Y., Chethana, K.W.T., Xiao, S., Zhu, S., Dai, Y., Peng, B., Yu, H., Yin, X., Wang, S., Yang, R., Deng, Y., Li, C., Zhang, Z., Hyde, K.D., Li, Y. \& Yuan, X. (2020) MushDB, a database that covers $90 \%$ of popular, cultivated mushrooms and reveals insights into their evolution and domestication. Fungal Diversity (In press).

Gazis, R., Kuo, A., Riley, R., LaButti, K., Lipzen, A., Lin, J., Amirebrahimi, M., Hesse, C.N., Spatafora, J.W., Henrissat, B. \& Hainaut, M. (2016) The genome of Xylona heveae provides a window into fungal endophytism. Fungal biology, 120, 26-42.

https://doi.org/10.1016/j.funbio.2015.10.002

Grossart, H.P., Wurzbacher, C., James, T.Y. \& Kagami, M. (2016) Discovery of dark matter fungi in aquatic ecosystems demands a reappraisal of the phylogeny and ecology of zoosporic fungi. Fungal Ecology, 19, 28-38. https://doi.org/10.1016/j.funeco.2015.06.004

Hawksworth, D.L., Hibbett, D.S., Kirk, P.M. \& Lücking R. (2018) (F-005-006) Proposals to permit DNA sequence data to be used as types of names of fungi. IMA Fungus, 9, V-VI.

Hibbett, D.S. (1992) Ribosomal RNA and fungal systematics. Transactions of the Mycological Society of Japan, 33, 533556.

Hibbett, D.S., Ohman, A., Glotzer, D., Nuhn, M., Kirk, P. \& Nilsson, 
R.H. (2011) Progress in molecular and morphological taxon discovery in Fungi and options for formal classification of environmental sequences. Fungal Biology Reviews, 25, 3847.

https://doi.org/10.1016/j.fbr.2011.01.001

Hong, S.B., Go, S.J., Shin, H.D., Frisvad, J.C. \& Samson, R.A. (2005) Polyphasic taxonomy of Aspergillus fumigatus and related species. Mycologia, 97, 1316-1329.

https://doi.org/10.1080/15572536.2006.11832738

Hongsanan, S., Jeewon, R., Purahong, W., Xie, N., Liu, J.K., Jayawardena, R.S., Ekanayaka, A.H., Dissanayake, A., Raspé, O., Hyde KD, Stadler, M. \& Peršoh, D. (2018) Can we use environmental DNA as holotypes? Fungal Diversity, 92, 1-30. https://doi.org/10.1007/s13225-018-0404-x

Hwang, U.W. \& Kim, W. (1999) General properties and phylogenetic utilities of nuclear ribosomal DNA and mitochondrial DNA commonly used in molecular systematics. The Korean journal of parasitology, 37, 215-228.

https://doi.org/10.3347/kjp.1999.37.4.215

Hyde, K.D., Jones, E.G., Leaño, E., Pointing, S.B., Poonyth, A.D. \& Vrijmoed, L.L. (1998). Role of fungi in marine ecosystems. Biodiversity \& Conservation, 7, 1147-1161. https://doi.org/10.1023/A:1008823515157

Hyde, K.D., McKenzie, E.H.C. \& KoKo, T.W. (2011) Towards incorporating anamorphic fungi in a natural classificationchecklist and notes for 2010. Mycosphere, 2, 1-88.

Hyde, K.D., Norphanphoun, C., Abreu, V.P., Bazzicalupo, A., Chethana, K.T., Clericuzio, M., Dayarathne, M.C., Dissanayake, A.J., Ekanayaka, A.H., He, M.Q., Hongsanan, S., Huang, S.K., Jayasiri, S.C., Jayawardena, R.S., Karunarathna, A., Konta, S., Kušan, I., Lee, H., Li, J., Lin, C.G., Liu, N.G., Lu, Y.Z., Luo, Z.L., Manawasinghe, I.S., Mapook, A., Perera, R.H., Phookamsak, R., Phukhamsakda, C., Siedlecki, I., Soares, A.M., Tennakoon, D., Tian, Q., Tibpromma, S., Wanasinghe, D.N., Xiao, Y.P., Yang, J., Zeng, X.Y., Abdel-Aziz, F.A., Li, W.J., Senanayake, I.C., Shang, Q.J., Daranagama, D.A., de Silva, N.I., Thambugala, K.M., Abdel- Wahab, M.A., Bahkali, A.H., Berbee, M.L., Boonmee, S., Bhat, D.J., Bulgakov, T.S., Buyck, B., Camporesi, E., Castaneda-Ruiz, R.F., Chomnunti, P., Doilom, M., Dovana, F., Gibertoni, T.B., Jadan, M., Jeewon, R., Jones, E.B.G., Kang, J.C., Karunarathna, S.C., Lim, Y.W., Liu, J.K., Liu, Z.Y., Plautz, H.L. Jr, Lumyong, S., Maharachchikumbura, S.S.N., Matocec, N., McKenzie, E.H.C., Mesic, A., Miller, D., Pawlowska, J., Pereira, O.L., Promputtha, I., Romero, A.I., Ryvarden, L., Su, H.Y., Suetrong, S., Tkalcec, Z., Vizzini, A., Wen, T.C., Wisitrassameewong, K., Wrzosek, M., Xu, J.C., Zhao, Q., Zhao, R.L. \& Mortimer, P. (2017a) Fungal diversity notes 603-708: taxonomic and phylogenetic notes on genera and species. Fungal Diversity, 87, 1-235.

https://doi.org/10.1007/s13225-017-0391-3

Hyde, K.D., Maharachchikumbura, S.S., Hongsanan, S., Samarakoon, M.C., Lücking, R., Pem, D., Harishchandra, D., Jeewon, R., Zhao, R.L., Xu, J.C. \& Liu, J.K. (2017b). The ranking of fungi: a tribute to David L. Hawksworth on his 70th birthday. Fungal Diversity, 84, 1-23. https://doi.org/10.1007/s13225-017-0383-3

Hyde, K.D., Chaiwan, N., Norphanphoun, C., Boonmee, S., Camporesi, E., Chethana, K.W.T., Dayarathne, M.C., de Silva, N.I., Dissanayake, A.J., Ekanayaka, A.H., Hongsanan, S., Huang, S.K., Jayasiri, S.C., Jayawardena, R.S., Jiang, H.B., Karunarathna, A., Lin, C.G., Liu, J.K., Liu, N.G., Lu, Y.Z.,
Luo, Z.L., Maharachchimbura, S.S.N., Manawasinghe, I.S., Pem, D., Perera, R.H., Phukhamsakda, C., Samarakoon, M.C., Senwanna, C., Shang, Q., Tennakoon, D.S., Thambugala, K.M., Tibpromma, S., Wanasinghe, D.N., Xiao, Y.P., Yang, J., Zeng, X.Y., Zhang, J.F., Zhang, S.N., Bulgakov, T.S., Bhat, D.J., Cheewangkoon, R., Goh, T.K., Jones, E.B.G., Kang, J.C., Jeewon, R., Liu, Z.Y., Lumyong, S., Kuo, C.H., McKenzie, E.H.C., Wen, T.C., Yan, J.Y. \& Zhao, Q. (2018) Mycosphere notes 169-224. Mycosphere, 9, 271-430.

Hyde, K.D., Xu, J.C., Rapior, S., Jeewon, R., Lumyong, S., Niego, A.G.T., Abeywickrama, P.D., Aluthmuhandiram, J.P.S., Brahamanage, R.S., Brooks, S., Chaiyasen, A., Chethana, K.W.T., Chomnunti, P., Chepkirui, K., Chuankid, B., de Silva, N.I., Doilom, M., Faulds, C., Gentekaki, E., Gopalan, V., Kakumyan, P., Harishchandra, D., Hemachandran, H., Hongsanan, S., Karunarathna, A., Karunarathna, S.C., Khan, S., Kumla, J., Jayawardena, R.S., Liu, N., Luangharn, T., Macabeo, A.P.G., Marasinghe, D.S., Meeks, D., Mortimer, P.E., Mueller, P., Nadir, S., Nataraja, K.N., Nontachaiyapoom, S., O'Brien, M., Penkhrue, W., Phukhamsakda, C., Shaanker Ramanan, U., Rathnayaka, A.R., Sadaba, R.S., Sandargo, B., Samarakoon, B.C., Tennakoon, D.S., Siva, R., Sriprom, W., Suryanarayanan, T.S., Sujarit, K., Suwannarach, N., Suwunwong, T., Thongbai, B., Thongklang, N., Wei, D., Wijesinghe, N.S., Winiski, J., Yan, J., Yasanthika, E. \& Stadler, M. (2019) The amazing potential of fungi, 50 ways we can exploit fungi industrially. Fungal Diversity, 97, 1-136. https://doi.org/10.1007/s13225-019-00430-9

Jayawardena, R.S., Purahong, W., Zhang, W., Wubet, T., Li, X.H., Liu, M., Zhao, W., Hyde, K.D., Liu, J.H. \& Yan, J. (2018) Biodiversity of fungi on Vitis vinifera L. revealed by traditional and high-resolution culture-independent approaches. Fungal Diversity, 90, 1-84. https://doi.org/10.1007/s13225-018-0398-4

Jeffroy, O., Brinkmann, H., Delsuc, F. \& Philippe, H. (2006) Phylogenomics: the beginning of incongruence?. Trends in Genetics, 22, 225-231. https://doi.org/10.1016/j.tig.2006.02.003

Katoch, A. \& Kapoor, P. (2014) Recent concepts in fungal taxonomy: A review. Journal of Agriculture and Allied Sciences, 3, 2335.

Karp, P.D., Riley, M., Paley, S.M. \& Pellegrini-Toole, A. (2002) The MetaCyc database. Nucleic Acids Research, 30, 59-61. https://doi.org/10.1093/nar/30.1.59

Kew Report, R.B.G. (2018) The state of the world's fungi report. Royal Botanic Gardens, Kew, 92 pp.

Kraichak, E., Crespo, A., Divakar, P.K., Leavitt, S.D. \& Thorsten Lumbsch, H. (2017) A temporal banding approach for consistent taxonomic ranking above the species level. Scientific Reports, 7, 2297. https://doi.org/10.1038/s41598-017-02477-7

Laurin, M. (2010) The subjective nature of Linnaean categories and its impact in evolutionary biology and biodiversity studies. Contributions to Zoology 79, 131-146. https://doi.org/10.1163/18759866-07904001

Liu, Y.J., Whelen, S. \& Hall, B.D. (1999) Phylogenetic relationships among ascomycetes: Evidence from an RNA polymerase II subunit. Molecular Biology and Evolution, 16, 1799-1808. https://doi.org/10.1093/oxfordjournals.molbev.a026092

Liu, Y., Steenkamp, E.T., Brinkmann, H., Forget, L., Philippe, H. \& Lang, B. F. (2009) Phylogenomic analyses predict sister group relationship of nucleariids and fungi and paraphyly of Zygomycetes with significant support. BMC Evolutionary 
Biology, 9, 272.

https://doi.org/10.1186/1471-2148-9-272

Liu, N.G., Ariyawansa, H.A., Hyde, K.D., Maharachchikumbura, S.S.N., Zhao, R.L., Phillips, A.J.L., Jayawardena, R.S., Thambugala, K.M., Dissanayake, A.J., Wijayawardene, N.N., Liu, J.K., Liu, Z.Y., Jeewon, R., Jones, E.B.G. \& Jumpathong, J. (2016) Perspectives into the value of genera, families and orders in classification. Mycosphere, 7, 1649-1668. https://doi.org/10.5943/mycosphere/7/11/3

Lücking, R., Kirk, P.M. \& Hawksworth, D.L. (2018) Sequencebased nomenclature: a reply to Thines et al. and Zamora et al. and provisions for an amended proposal. IMA Fungus, 9, 185-198. https://doi.org/10.5598/imafungus.2018.09.01.12

Lücking, R. (2019) Stop the Abuse of Time! Strict Temporal Banding is not the future of rank-Based classifications in Fungi (Including Lichens) and other organisms. Critical Reviews in Plant Sciences, 38, 199-253. https://doi.org/10.1080/07352689.2019.1650517

Lutzoni, F., KauV, F., Cox, C.J., McLaughlin, D., Celio, G., Dentinger, B., Padamsee, M., Hibbett, D., James, T.Y., Baloch, E., Grube, M., Reeb, V., Hofstetter, V., Schoch, C., Arnold, A.E., Miadlikowska, J., Spatafora, J., Johnson, D., Hambleton, S., Crockett, M., Shoemaker, R., Sung, G.-H., Lucking, R., Lumbsch, T., O’Donnell, K., Binder, M., Diederich, P., Ertz, D., Gueidan, C., Hansen, K., Harris, R.C., Hosaka, K., Lim, Y.-W., Matheny, B., Nishida, H., PWster, D., Rogers, J., Rossman, A., Schmitt, I., Sipman, H., Stone, J., Sugiyama, J., Yahr, R. \& Vilgalys, R. (2004) Assembling the fungal tree of life: progress, classification, and evolution of subcellular traits. American Journal of Botany, 91, 1446-1480. https://doi.org/10.3732/ajb.91.10.1446

Mallard, F., Noble, L., Guzella, T., Afonso, B., Baer, C.F. \& Teotónio, H. (2019) Selection and drift determine phenotypic stasis despite genetic divergence. bioRxiv, p. 778282. https://doi.org/10.1101/778282

McNeill, J., Barrie, F.R., Buck, W.R., Demoulin, V., Greuter, W., Hawksworth, D.L., Herendeen, P.S., Knapp, S., Marhold, K., Prado, J., Reine, P.V., Smith, G.F., Wiersema, J.H. \& Turland, N.J. (2012) International Code of Nomenclature for algae, fungi and plants (Melbourne Code) adopted by the Eighteenth International Botanical Congress Melbourne, Australia, July 2011. Publ. 2012. Regnum Vegetabile 154. Koeltz Scientific Books.

Maharachchikumbura, S.S.N., Hyde, K.D., Jones, E.B.G., McKenzie, E.H.C., Bhat, D.J., Dayarathne, M.C., Huang, S.K., Norphanphoun, C., Senanayake, I.C., Perera, R.H., Shang, Q.J., Xiao, Y.P., Souza, M.J., Hongsanan, S., Jayawardena, R.S., Daranagama, D.A., Konta, S., Goonasekara, I.D., Zhuang, W.Y., Jeewon, R., Phillips, A.J.L., Abdel Wahab, M.A., Al-Sadi, A.M., Bahkali, A.H., Boonmee, S., Boonyuen, N., Cheewangkoon, R., Dissanayake, A.J., Kang, J.C., Li, Q.R., Liu, J.K., Liu, X.Z., Liu, Z.Y., Luangsaard, J.J., Pang, K.L., Phookamsak, R., Promputtha, I., Suetrong, S., Stadler, M., Wen, T.C. \& Wijayawardene, N.N. (2016) Families of Sordariomycetes. Fungal Diversity, 79, 1-317. https://doi.org/10.1007/s13225-016-0369-6

Margulies, M., Egholm, M., Altman, W.E., Attiya, S., Bader, J.S., Bemben, L.A., Berka, J., Braverman, M.S., Chen, Y.J., Chen, Z., Dewell, S.B., Du, L., Fierro, J.M., Gomes, X.V., Godwin, B.C., He, W., Helgesen, S., Ho, C.H., Irzyk, G.P., Jando, S.C., Alenquer, M.L., Jarvie, T.P., Jirage, K.B., Kim, J.B., Knight, J.R., Lanza, J.R., Leamon, J.H., Lefkowitz, S.M., Lei, M., Li,
J., Lohman, K.L., Lu, H., Makhijani, V.B., McDade, K.E., McKenna, M.P., Myers, E.W., Nickerson, E., Nobile, J.R., Plant, R., Puc, B.P., Ronan, M.T., Roth, G.T., Sarkis, G.J., Simons, J.F., Simpson, J.W., Srinivasan, M., Tartaro, K.R., Tomasz, A., Vogt, K.A., Volkmer, G.A., Wang, S.H., Wang, Y., Weiner, M.P., Yu, P., Begley, R.F. \& Rothberg, J.M. (2005) Genome sequencing in microfabricated high-density picolitre reactors. Nature, 437, 376-380.

https://doi.org/10.1038/nature03959

McDermott, J., Guerquin, M., Frazier, Z., Chang, A.N. \& Samudrala, R. (2005) BIOVERSE: enhancements to the framework for structural, functional and contextual modeling of proteins and proteomes. Nucleic Acids Research, 33, W324-W325. https://doi.org/10.1093/nar/gki401

Nagy, L.G. \& Szöllősi, G. (2017) Fungal phylogeny in the age of genomics: insights into phylogenetic inference from genomescale datasets. Advances in genetics, 100, 49-72. https://doi.org/10.1016/bs.adgen.2017.09.008

Nilsson, R.H., Larsson, K.H., Taylor, A.F.S., Bengtsson-Palme, J., Jeppesen, T.S., Schigel, D., Kennedy, P., Picard, K., Glöckner, F.O., Tedersoo, L. \& Saar, I. (2019) The UNITE database for molecular identification of fungi: handling dark taxa and parallel taxonomic classifications. Nucleic acids research, 47, D259-D264.

https://doi.org/10.1093/nar/gky1022

Peršoh, D. (2015) Plant-associated fungal communities in the light of metaomics. Fungal Diversity, 75, 1-25. https://doi.org/10.1007/s13225-015-0334-9

Phillips, A.J.L, Hyde, K.D., Alves, A. \& Liu, J.K (Jack). (2019) Families in Botryosphaeriales: a phylogenetic, morphological and evolutionary perspective. Fungal Diversity, 94, 1-22. https://doi.org/10.1007/s13225-018-0416-6

Roeckel-Drevet, P., Coelho, V., Tourvieille, J., Nicolas, P. \& Tourvieille De Labrouhe, D. (1997) Lack of genetic variability in French identified races of Plasmopara halstedii, the cause of downy mildew in sunflower Helianthus annuus. Canadian Journal of Microbiology, 43, 260-263. https://doi.org/10.1139/m97-036

Ryberg, M. \& Nilsson, R.H. (2018) New light on names and naming of dark taxa. MycoKeys, 23, 31-39. https://doi.org/10.3897/mycokeys.30.24376

Samarakoon, M.C., Hyde, K.D., Promputtha, I., Ariyawansa, H.A. $\&$ Hongsanan, S. (2016) Divergence and ranking of taxa across the kingdoms Animalia, Fungi and Plantae. Mycosphere, 7, 1678-1689. https://doi.org/10.5943/mycosphere/7/11/5

Schmidt, T.S., Rodrigues, J.F.M. \& Mering, C.V. (2014) Ecological consistency of SSU rRNA-based operational taxonomic units at a global scale. PLoS Computional Biology, 10, e1003594. https://doi.org/10.1371/journal.pcbi.1003594

Schoch, C.L., Wang, Z., Townsend, J.P. \& Spatafora, J.W. (2009) Geoglossomycetes cl. nov., Geoglossales ord. nov., and taxa above class rank in the Ascomycota tree of life. Persoonia, 22, 129-138.

https://doi.org/10.3767/003158509X461486

Schoch, C.L., Seifert, K.A., Huhndorf, S., Robert, V., Spouge, J.L., Levesque, C.A. \& Chen, W. (2012) Nuclear ribosomal internal transcribed spacer (ITS) region as a universal DNA barcode marker for Fungi. Proceedings in National Academy of Sciences USA, 109, 6241-6246.

https://doi.org/10.1073/pnas.1117018109

Som, A. (2015) Causes, consequences and solutions of phylogenetic incongruence. Briefings in Bioinformatics, 16, 536-548. 
https://doi.org/10.1093/bib/bbu015

Spatafora, J.W., Chang, Y., Benny, G.L., Lazarus, K., Smith, M.E., Berbee, M.L., Bonito, G., Corradi, N., Grigoriev, I., Gryganskyi, A. \& James, T.Y. (2016) A phylum-level phylogenetic classification of zygomycete fungi based on genome-scale data. Mycologia, 108, 1028-1046.

https://doi.org/10.3852/16-042

Spatafora, J.W., Aime, M.C., Grigoriev, I.V., Martin, F., Stajich, J.E. \& Blackwell, M. (2017) The fungal tree of life: from molecular systematics to genome-scale phylogenies. The fungal kingdom, 1-34.

https://doi.org/10.1128/9781555819583.ch1

Tatusov, R.L., Fedorova, N.D., Jackson, J.D., Jacobs, A.R., Kiryutin, B., Koonin, E.V., Krylov, D.M., Mazumder, R., Mekhedov, S.L., Nikolskaya, A.N., Rao, B.S., Smirnov, S., Sverdlov, V., Vasudevan, S., Wolf, Y.I., Yin, J.J. \& Natale, D.A. (2003). The COG database: an updated version includes eukaryotes. $B M C$ Bioinformatics, 4, 41. https://doi.org/10.1186/1471-2105-4-41

Tedersoo, L., Sánchez-Ramírez, S., Koljalg, U., Bahram, M., Döring, M., Schigel, D., May, T., Ryberg, M. \& Abarenkov, K. (2018) High-level classification of the Fungi and a tool for evolutionary ecological analyses. Fungal Diversity, 90, $135-159$.

https://doi.org/10.1007/s13225-018-0401-0

Vasilyeva, L.N. \& Stephenson, S.L. (2010) The problems of traditional and phylogenetic taxonomy of fungi. Mycosphere, $1,45-51$.

Wijayawardene, N.N., Hyde, K.D., Rajeshkumar, K.C., Hawksworth, D.L., Madrid, H., Kirk, P.M., Braun, U., Singh, R.V., Crous, P.W., Kukwa, M., Lücking, R., Kurtzman, C.P., Yurkov, A., Haelewaters, D., Aptroot, A., Lumbsch, H.T., Timdal, E., Ertz, D., Etayo, J., Phillips, A.J.L., Groenewald, J.Z., Papizadeh, M., Selbmann, L., Dayarathne, M.C., Weerakoon, G., Jones, E.B.G., Suetrong, S., Tian, Q., Castañeda-Ruiz, R.F., Bahkali, A.H., Pang, K.-L., Tanaka, K., Dai, D.Q., Sakayaroj, J., Hujslová, M., Lombard, L., Shenoy, B.D., Suija, A., Maharachchikumbura, S.S.N., Thambugala, K.M., Wanasinghe, D.N., Sharma, B.O., Gaikwad, S., Pandit, G., Zucconi, L., Onofri, S., Egidi, E., Raja, H.A., Kodsueb, R., Cáceres, M.E.S., Pérez-Ortega, S., Fiuza, P.O., Monteiro, J.S., Vasilyeva, L.N., Shivas, R.G., Prieto, M., Wedin, M., Olariaga, I., Lateef, A.A., Agrawal, Y., Fazeli, S.A.S., Amoozegar, M.A., Zhao, G.Z., Pfliegler, W.P., Sharma, G., Oset, M., Abdel-Wahab, M.A., Takamatsu, S., Bensch, K., de Silva, N.I., De Kese, A., Karunarathna, A., Boonmee, S., Pfister, D.H., Lu, Y.-Z., Luo, Z.-L., Boonyuen, N., Daranagama, D.A., Senanayake, I.C., Jayasiri, S.C., Samarakoon, M.C., Zeng, X.-Y., Doilom, M., Quijada, L., Rampadarath, S., Heredia, G., Dissanayake, A.J., Jayawardana, R.S., Perera, R.H., Tang, L.Z., Phukhamsakda, C., Hernández-Restrepo, M., Ma, X., Tibpromma, S., Gusmao, L.F.P., Weerahewa, D. \& Karunarathna, S.C. (2017) Notes for genera-Ascomycota. Fungal Diversity, 86, 1-594. https://doi.org/10.1007/s13225-017-0386-0

Wijayawardene, N.N., Hyde, K.D., Lumbsch, T., Liu, J.K., Maharachchikumbura, S.S.N., Ekanayaka, A.H., Tian, Q. \& Phookamsak, R. (2018a) Outline of Ascomycota-2017. Fungal Diversity, 88, 167-263. https://doi.org/10.1007/s13225-018-0394-8

Wijayawardene, N.N., Pawłowska, J., Letcher, P.M., Kirk, P.M., Humber, R.A., Schüßler, A., Wrzosek, M., Muszewska, A., Okrasinska, A., Istel, L., Gesiorska, A., Mungai, P.,
Lateef, A.A., Rajeshkumar, K.C., Singh, R.V., Radek, R., Walther, G., Wagner, L., Walker, C., Wijesundara, D.S.A., Papizadeh, M., Dolatabadi, S., Shenoy, B.D., Tokarev, Y.S., Lumyong, S. \& Hyde, K.D. (2018b) Notes for genera: basal clades of Fungi (including Aphelidiomycota, Basidiobolomycota, Blastocladiomycota, Calcarisporiellomycota, Caulochytriomycota, Chytridiomycota, Entomophthoromycota, Glomeromycota, Kickxellomycota, Monoblepharomycota, Mortierellomycota, Mucoromycota, Neocallimastigomycota, Olpidiomycota, Rozellomycota and Zoopagomycota). Fungal Diversity, 92, 43-129.

https://doi.org/10.1007/s13225-018-0409-5

Wiley, E.O. \& Lieberman, B.S. (2011) Phylogenetics: theory and practice of phylogenetic systematics. John Wiley \& Sons: New Jersey, 432 pp.

Williams, J.G., Kubelik, A.R., Livak, K.J., Rafalski, J.A. \& Tingey, S.V. (1990) DNA polymorphisms amplified by arbitrary primers are useful as genetic markers. Nucleic acids research, $18,6531-6535$. https://doi.org/10.1093/nar/18.22.6531

Wingfield, M.J., De Beer, Z.W., Slippers, B., Wingfield, B.D., Groenewald, J.Z., Lombard, L. \& Crous, P.W. (2012) One fungus, one name promotes progressive plant pathology. Molecular Plant Pathology, 13, 604-613. https://doi.org/10.1111/j.1364-3703.2011.00768.x

Womack, A.M., Artaxo, P.E., Ishida, F.Y., Mueller, R.C., Saleska, S.R., Wiedemann, K.T., Bohannan, B.J.M. \& Green, J.L. (2015) Characterization of active and total fungal communities in the atmosphere over the Amazon rainforest. Biogeosciences, 12, 6337-6349. https://doi.org/10.5194/bg-12-6337-2015

Wu, B., Hussain, M., Zhang, W., Stadler, M., Liu, X. \& Xiang, M. (2019) Current insights into fungal species diversity and perspective on naming the environmental DNA sequences of fungi. Mycology, 10, 127-140.

https://doi.org/10.1080/21501203.2019.1614106

$\mathrm{Xu}$, J. (2006) Fundamentals of fungal molecular population genetic analyses. Current issues in molecular biology, 8, 75.

Young, A.D. \& Gillung, J.P. (2020) Phylogenomics-principles, opportunities and pitfalls of big-data phylogenetics. Systematic Entomology, 45, 225-247.

https://doi.org/10.1111/syen.12406.

Zhang, N., Castlebury, L.A., Miller, A.N., Huhndorf, S.M., Schoch, C.L. Seifert, K.A., Rossman, A.Y., Rogers, J.D., Kohlmeyer, J., Volkmann-Kohlmeyer, B. \& Sung, G.H. (2006) An overview of the systematics of the Sordariomycetes based on a four-gene phylogeny. Mycologia, 98, 1076-1087. https://doi.org/10.1080/15572536.2006.11832635

Zhao, R.L., Zhou, J.L., Chen, J., Margaritescu, S., SánchezRamírez, S., Hyde, K.D., Callac, P., Parra, L.A., Li, G.J. \& Moncalvo, J.M. (2016) Towards standardizing taxonomic ranks using divergence times - a case study for reconstruction of the Agaricus taxonomic system. Fungal Diversity, 78, 239-292. https://doi.org/10.1007/s13225-016-0357-x

Zhao, R.L., Li, G.J., Sánchez-Ramírez, S., Stata, M., Yang, Z.L., Wu, G., Dai, Y.C., He, S.H., Cui, B.K., Zhou, J.L., Wu, F., He, M.Q., Moncalvo, J.M. \& Hyde, K.D. (2017) A sixgene phylogenetic overview of Basidiomycota and allied phyla with estimated divergence times of higher taxa and a phyloproteomics perspective. Fungal Diversity, 84, 43-74. https://doi.org/10.1007/s13225-017-0381-5 